\title{
Identification of Elite Wood apple Genotypes for Physical Characters in Selected Districts of Karnataka, India
}

\author{
M. Y. Sridhar ${ }^{1}$, K. H. Nataraja ${ }^{1}$, Nagesh Naik $^{1}$, D. Satish ${ }^{2}$, A. Dileepkumar, \\ Masuthi $^{3}$ and Smt. Manjula Karadiguddi ${ }^{4}$ \\ ${ }^{1}$ Department of fruit Science KRC College of Horticulture Arabhavi, India \\ ${ }^{2}$ Department of Biotech and Crop Improvement, College of Horticulture Bagalkot, India \\ ${ }^{3}$ Department of Biotech and Crop Improvement, ${ }^{4}$ Department of Post-Harvest Technology, \\ KRC College of Horticulture, Arabhavi, India
}

*Corresponding author

\section{A B S T R A C T}

\begin{tabular}{|l|}
\hline K e y w o r d s \\
Feronia limonia, \\
Rutaceae, \\
community lands, \\
Roman Goddess
\end{tabular}

\section{Introduction}

Wood apple (Feronia limonia), is also called as elephant apple, monkey fruit, curd fruit, Kath bel and other dialectal names in India. It is the only species of its genus, in the
In Wood apple the existing variability is low due to the problem of unexploitation and lack of awareness. However, to some extent variation is seen in the genotypes with respect to morphological, physico-chemical parameters and also in productivity. In any crop, the improvement by selection method involves identification of superior types from a genetic population. Thus variability in the population is a pre-requisite for crop improvement and is considered as a boon to a plant breeder. As variability makes pre - requisite for selection criteria, it is the most quickest and effective method of breeding, particularly in perennial crops. Hence, the present research was carried through survey of eighty six genotypes from selected districts of Karnataka like Bijapur, Belgaum, Haveri, Shivamogga, Davangere, Chitradurga and Tumukur district during the fruiting season of 2018-19. The trees were used for studying the physical characters and the observations on various parameters of tree were recorded. Among 86 genotypes surveyed, 49 genotypes were found small type, 27 genotypes were medium and 10 were large type of genotypes. The tree girth ranged from $18.00 \mathrm{~cm}$ to $230 \mathrm{~cm}$ with an average plant girth of $103.47 \mathrm{~cm}, 28$ genotypes have light brown colored bark where as 58 genotypes have dark brown colored bark while, 40 genotypes and 35 genotypes are semi spreading and 11 genotypes were erect type of branching habit and 52 genotypes shown oval type of canopy and 34 genotypes exhibit round shape of canopy. 
forests. It prefers slightly acidic soil but can be grown on a variety of soils. Its cultivation as a fruit tree is rare, but fruits of naturally occurring trees in community lands, forests and on road sides are used for chutney and pickle making. The wood apple is mainly found in forest and dry plain area of Indian subcontinents. The age of the plant varies from 13 to 70 years with yield potentiality in mother plants varying from 650 to $1085 \mathrm{~kg}$ of fruit per plant having the fruit weight between 130 and $225 \mathrm{gm}$. Fruit length varies between 7.3 to $8.9 \mathrm{~cm}$ while breadth between 7.2 and $8.4 \mathrm{~cm}$. Fruit size (length $\times$ breadth) varies in relation to fruit weight. Wood apple has high nutritional value. The pulp is pleasant and sweet, contains 2.66 per cent pectin, 64.2 per cent moisture, 7.1 per cent protein, 3.7 per cent fat, 1.9 per cent minerals, 50 per cent fiber, 18.1 per cent carbohydrates, 0.13 per cent calcium, 0.11 per cent phosphorus and 0.048 per cent iron (Raghvendra et al., 2011).In order to address the above points, the survey was carried out in selected districts of Karnataka likelike Bijapur, Belgaum, Haveri, Shivamogga, Davangere, Chitradurga and Tumukur district during the fruiting season of 2018-19.

\section{Materials and Methods}

During the survey work 86 genotypes were selected from different locations of Karnataka Selected genotype each from Mallavali, Taradhalli and Balekoppa, Selected two genotypes each from Kanakapur and Mallapur, Three genotypes were selected each from Dupdhal, Tatur Jc pura and Maradur, Four genotypes were selected each from Chitrahalli and Allur, Five wood apple genotypes were selected each from Devarhipargi, Honalli cross, Ecchalgata and Ramanhalli. Six genotypes from Dwarahalli, Seven genotypes from Godachi, Eleven genotypes from Hanumanhalli and Thirteen genotypes were selected from Bellar farm,
Total 86 genotypes which were bearing stage during survey was selected during 2018 december to 2019 january.

\section{Tree height (m)}

The tree height was recorded based on visual observations and they are categorized in to three different groups like, large height $(>12$ $\mathrm{m})$, medium height $(8-12 \mathrm{~m})$ and low height types $(<8 \mathrm{~m})$.

\section{Shape of canopy}

The shape of canopy was recorded based on visual observations and they are categorized in to round type and oval type.

\section{Branching / spreading}

Tree growth habit is recorded by visual appearance of the tree and they are grouped in spreading type, semi-spreading type and erect type.

\section{Bark colour}

The bark colour of the tree are grouped in two types viz., light brown and dark brown and recorded by visual observations.

\section{Tree girth $(\mathrm{cm})$}

The tree girth was calculated by measuring circumference $\left(2^{\pi} \mathrm{r}\right)$ of the tree at a height of $60 \mathrm{~cm}$ from the ground level with the help of a measuring tape and was expressed in centimeters.

\section{Statistical Analysis}

The analysis of variance for each character was carried out by taking the mean value of each treatment under each replication at department of Fruit Science, KRCCHArabhavi. 


\section{Results and Discussion}

Various growth characters viz., plant height, trunk diameter and plant canopy spread were studied.

Among 86 genotypes surveyed, 49 genotypes were found small type, 27 genotypes were medium and 10 were large type of genotypes. which may be due to some amount of genetic and environmental conditions. This was in concurrence with the earlier findings of Sappandi et al., (2005) in wood apple Abhilash et al., (2018) in kagzi lime. Similarly, trunk diameter is an important character which contributes significantly on yield of plant as it supports primary branches as well as secondary branches essential for fruit bearingIn the present study, the trunk girth ranged from $18.00 \mathrm{~cm}$ to $230 \mathrm{~cm}$ with an average plant girth of $103.47 \mathrm{~cm}$. Highest plant girth of $230 \mathrm{~cm}$ was recorded in genotype Ls-72 followed by Ls-70 $(210 \mathrm{~cm})$, Ls-59 and Ls-69 (200 cm each) and the lowest girth was recorded in Ls-5 $(18 \mathrm{~cm})$ which is followed by both Ls- 6 and Ls-1 (25 cm each) genotypeswhich may be due to some amount of genetic influence similar findings were noticed in Sappandi et al., (2005in wood apple Abhilash et al., (2018) in kagzi lime. Among 86 genotypes surveyed, 52 genotypes shown oval type of canopy and 34 genotypes exhibit round shape of canopy. While may be due to influence of environmental conditions and genetic influence. Similar findings were noticed in

Table.1Variability for morphological traits of wood apple trees

\begin{tabular}{|c|c|c|c|c|c|c|c|}
\hline $\begin{array}{c}\text { Sl. } \\
\text { No. }\end{array}$ & Genotypes & $\begin{array}{c}\text { Tree } \\
\text { height } \\
\text { (m) }\end{array}$ & $\begin{array}{c}\text { Tree } \\
\text { girth } \\
\mathbf{( c m})\end{array}$ & Bark colour & Branching habit & $\begin{array}{c}\text { Shape of } \\
\text { canopy }\end{array}$ \\
\hline $\mathbf{1}$ & & \multicolumn{2}{|c|}{ Low height type } \\
\hline $\mathbf{2}$ & Ls-60 & 4 & 60 & Light Brown & Semi-Spreading & Oval \\
\hline $\mathbf{3}$ & Ls-32 & 4 & 110 & Dark Brown & Spreading & Oval \\
\hline $\mathbf{4}$ & Ls-14 & 5 & 132 & Dark Brown & Semi-Spreading & Round \\
\hline $\mathbf{5}$ & Ls-33 & 5 & 80 & Light Brown & Semi-Spreading & Oval \\
\hline $\mathbf{6}$ & Ls-20 & 6 & 60 & Dark Brown & Semi-Spreading & Round \\
\hline $\mathbf{7}$ & Ls-22 & 6 & 80 & Light Brown & Erect & Oval \\
\hline $\mathbf{8}$ & Ls-34 & 6 & 730 & Light Brown & Erect & Oval \\
\hline $\mathbf{9}$ & Ls-35 & 6 & 95 & Dark Brown & Semi-Spreading & Oval \\
\hline $\mathbf{1 0}$ & Ls-38 & 6 & 105 & Dark Brown & Semi-Spreading & Oval \\
\hline $\mathbf{1 1}$ & Ls-39 & 6 & 110 & Dark Brown & Spreading & Round \\
\hline $\mathbf{1 2}$ & Ls-40 & 6 & 125 & Dark Brown & Spreading & Oval \\
\hline $\mathbf{1 3}$ & Ls-48 & 6 & 60 & Dark Brown & Spreading & Round \\
\hline $\mathbf{1 4}$ & Ls-53 & 6 & 100 & Dark Brown & Spreading & Round \\
\hline $\mathbf{1 5}$ & Ls-54 & 6 & 140 & Dark Brown & Semi-Spreading & Oval \\
\hline $\mathbf{1 6}$ & Ls-57 & 6 & 130 & Light Brown & Spreading & Oval \\
\hline $\mathbf{1 7}$ & Ls-62 & 6 & 120 & Light Brown & Spreading & Round \\
\hline $\mathbf{1 8}$ & Ls-63 & 6 & 85 & Light Brown & Erect & Oval \\
\hline $\mathbf{1 9}$ & Ls-80 & 6 & 75 & Dark Brown & Spreading & Round \\
\hline $\mathbf{2 0}$ & Ls-82 & 6 & 80 & Dark Brown & Semi Spreading & Oval \\
\hline $\mathbf{2 1}$ & Ls-85 & 6 & 90 & Dark Brown & Semi Spreading & Oval \\
\hline $\mathbf{2 2}$ & Ls-86 & 6 & 110 & Dark Brown & Semi Spreading & Round \\
\hline
\end{tabular}




\begin{tabular}{|c|c|c|c|c|c|c|}
\hline 23 & Ls-16 & 7 & 80 & Dark Brown & Semi-Spreading & Oval \\
\hline 24 & Ls-17 & 7 & 80 & Dark Brown & Semi-Spreading & Oval \\
\hline 25 & Ls-23 & 7 & 80 & Light Brown & Spreading & Oval \\
\hline 26 & Ls-24 & 7 & 70 & Light Brown & Spreading & Oval \\
\hline 27 & Ls-26 & 7 & 110 & Dark Brown & Spreading & Oval \\
\hline 28 & Ls-29 & 7 & 180 & Dark Brown & Semi-Spreading & Oval \\
\hline 29 & Ls-31 & 7 & 165 & Dark Brown & Spreading & Oval \\
\hline 30 & Ls-36 & 7 & 90 & Dark Brown & Semi-Spreading & Oval \\
\hline 31 & Ls-37 & 7 & 95 & Dark Brown & Semi-Spreading & Oval \\
\hline 32 & Ls-41 & 7 & 120 & Dark Brown & Semi-Spreading & Oval \\
\hline 33 & Ls-42 & 7 & 80 & Dark Brown & Spreading & Oval \\
\hline 34 & Ls-43 & 7 & 110 & Dark Brown & Erect & Oval \\
\hline 35 & Ls-45 & 7 & 145 & Dark Brown & Spreading & Round \\
\hline 36 & Ls-46 & 7 & 85 & Dark Brown & Spreading & Round \\
\hline 37 & Ls-47 & 7 & 60 & Dark Brown & Erect & Round \\
\hline 38 & Ls-49 & 7 & 65 & Dark Brown & Erect & Round \\
\hline 39 & Ls-52 & 7 & 90 & Dark Brown & Spreading & Oval \\
\hline 40 & Ls-56 & 7 & 157 & Dark Brown & Spreading & Round \\
\hline 41 & Ls-58 & 7 & 75 & Light Brown & Semi-Spreading & Round \\
\hline 42 & Ls-64 & 7 & 50 & Light Brown & Semi Spreading & Oval \\
\hline 43 & Ls-66 & 7 & 165 & Light Brown & Spreading & Round \\
\hline 44 & Ls-74 & 7 & 85 & Dark Brown & Spreading & Round \\
\hline 45 & Ls-77 & 7 & 183 & Dark Brown & Spreading & Oval \\
\hline 46 & Ls-78 & 7 & 95 & Dark Brown & Semi Spreading & Round \\
\hline 47 & Ls-79 & 7 & 65 & Dark Brown & Semi Spreading & Round \\
\hline 48 & Ls-81 & 7 & 75 & Dark Brown & Semi Spreading & Round \\
\hline 49 & Ls-83 & 7 & 78 & Dark Brown & Semi Spreading & Round \\
\hline \multicolumn{7}{|c|}{ Medium height type } \\
\hline 50 & Ls-18 & 8 & 70 & Dark Brown & Semi-Spreading & Round \\
\hline 51 & Ls-25 & 8 & 80 & Light Brown & Spreading & Oval \\
\hline 52 & Ls-44 & 8 & 130 & Dark Brown & Spreading & Round \\
\hline 53 & Ls-10 & 9 & 120 & Light Brown & Spreading & Oval \\
\hline 54 & Ls-13 & 9 & 135 & Light Brown & Spreading & Oval \\
\hline 55 & Ls-21 & 9 & 60 & Light Brown & Erect & Oval \\
\hline 56 & Ls-27 & 9 & 140 & Dark Brown & Spreading & Oval \\
\hline 57 & Ls-28 & 9 & 150 & Dark Brown & Spreading & Oval \\
\hline 58 & Ls-30 & 9 & 110 & Dark Brown & Semi-Spreading & Oval \\
\hline 59 & Ls-50 & 9 & 145 & Dark Brown & Erect & Round \\
\hline 60 & Ls-59 & 9 & 200 & Light Brown & Spreading & Round \\
\hline 61 & Ls-65 & 9 & 140 & Light Brown & Semi Spreading & Round \\
\hline 62 & Ls-67 & 9 & 110 & Dark Brown & Spreading & Round \\
\hline 63 & Ls-72 & 9 & 230 & Dark Brown & Spreading & Round \\
\hline 64 & Ls-75 & 9 & 110 & Dark Brown & Semi Spreading & Oval \\
\hline 65 & Ls-84 & 9 & 100 & Dark Brown & Spreading & Oval \\
\hline 66 & Ls-6 & 10 & 25 & Light Brown & Spreading & Round \\
\hline 67 & Ls-9 & 10 & 125 & Light Brown & Semi-Spreading & Round \\
\hline 68 & Ls-11 & 10 & 125 & Light Brown & Spreading & Oval \\
\hline
\end{tabular}




\begin{tabular}{|c|c|c|c|c|c|c|}
\hline 69 & Ls-12 & 10 & 160 & Dark Brown & Spreading & Oval \\
\hline 70 & Ls-19 & 10 & 132 & Light Brown & Erect & Oval \\
\hline 71 & Ls-51 & 10 & 85 & Dark Brown & Spreading & Oval \\
\hline 72 & Ls-55 & 10 & 158 & Dark Brown & Spreading & Round \\
\hline 73 & Ls-61 & 10 & 140 & Light Brown & Spreading & Oval \\
\hline 74 & Ls-71 & 10 & 85 & Dark Brown & Semi Spreading & Oval \\
\hline 75 & Ls-73 & 10 & 150 & Dark Brown & Spreading & Round \\
\hline 76 & Ls-76 & 10 & 110 & Dark Brown & Semi Spreading & Oval \\
\hline \multicolumn{7}{|c|}{ Large height type } \\
\hline 77 & Ls-1 & 12 & 25 & Dark Brown & Spreading & Oval \\
\hline 78 & Ls-7 & 12 & 100 & Light Brown & Semi-Spreading & Oval \\
\hline 79 & Ls-68 & 12 & 130 & Light Brown & Semi Spreading & Oval \\
\hline 80 & Ls-69 & 12 & 200 & Light Brown & Spreading & Round \\
\hline 81 & Ls-8 & 14 & 80 & Dark Brown & Semi-Spreading & Oval \\
\hline 82 & Ls-70 & 14 & 210 & Light Brown & Semi Spreading & Oval \\
\hline 83 & Ls-5 & 15 & 18 & Light Brown & Semi-Spreading & Oval \\
\hline 84 & Ls-2 & 18 & 75 & Dark Brown & Erect & Oval \\
\hline 85 & Ls-3 & 30 & 200 & Dark Brown & Erect & Round \\
\hline 86 & Ls-4 & 30 & 200 & Dark Brown & Spreading & Round \\
\hline \multicolumn{2}{|c|}{ Mean } & 8.51 & 103.47 & & & \\
\hline \multicolumn{2}{|c|}{ Range } & $4-30$ & $20-230$ & & & \\
\hline
\end{tabular}

The trees were observed for branching habit during the course of survey and found to produce spreading type in 40 genotypes and 35 genotypes are semi spreading and 11 genotypes were erect type of branching habit out of 86 genotypes surveyed. While may be due to influence of environmental conditions and genetic influence similar findings were noticed in charoli by kareedy (2003) Pavani et $a l$, in bael (2017)Among 86 genotypes surveyed 28 genotypes have light brown colored bark where as 58 genotypes have dark brown colored bark. It may be due to influence of environmental conditions and genetic influence similar findings were noticed by Kareedy in charoli (2003) Sappandi et al.,in wood apple(2005).

\section{Acknowledgements}

Mr. Nataraja K. H Department of Fruit Science, Kittur Rani Channamma College of Horticulture, Arabhavi had continuous supported to my research including the selection of topic and procedure to conduct the research. Dr. Nagesh Naik, Professor and Head, Department of Fruit Science, Kittur Rani Channamma College of Horticulture, Arabhavi Dr. Satish, Asst. Professor, Department of BCI, Kittur Rani Channamma College of Horticulture, Arabhavi has helped in laying out the design and analysis of the results. Dr. Dileepkumar A. Masuthi Assistant Professor,(Seed tech.) Dept of Biotech and Crop Improvement, KRCCH, Arabhavi and Smt. Manjula Karadiguddi, Assistant Professor Dept. of Post-Harvest Technology, $\mathrm{KRCCH}$, Arabhavi for their constant supervision, invaluable guidance and all the facilities extended during the course of this investigation.

\section{References}

Abhilash, K., Kerutagi, G. M., Rashmi, K., Satish, D. and Nagesh, N., 2018, Evaluation of the elite strains of acid lime (Citrus aurantifolia Swingle L.) for the growth and yield parameters.Int. J. Curr. Microbiol. 
$\begin{array}{lll}\text { Appl. } & \text { Sci., } & \text { 7(7): }\end{array}$ 666-677.

Bajpai, P. N. and Chaturvedi, O. P., 1990, Jamun; In fruits: Tropical and subtropical. Ed. Bose, T. K. and Mitra, S. S., Naya prakash, Calcutta, 747-756.

Desai, U. T. and Ranpise, S. A., 1995, Sai sharbati (rhr-1-49) new promising acid lime cultivars for western Maharashtra. Madras Agril. J.,82(9-10: 562-563.

Inamdar, S. R., 2000, Survey, evaluation of seedling progenies and standardization of clonal propagation in jamun. M.Sc.(Hort.) Thesis, Univ. Agril. Sci., Dharwad. (India).

Jauhari, O. S., Singh, R. D. and Aswathi, R. K., 1969, Survey of some important verities of bael (Aegle marmelos). The Punjab Hort. J., 9(1-2): 48-53.

Kareddy, S., 2003, Survey, evaluation and propagation of charoli (Buchanania iuzan). M.sc (Hort) Thesis, University of Agricultural Sciences, Dharwad. (India).

Pavani, P., Kiranmayi, P. and Das, S. N., 2017, Evaluation of bael (Aegle marmelos Correa) for morphological, quality and yield related characters. International J. Basic Appl. Biol., 4(3): $164-167$.

Sappandi, S., 2005, Survey, evaluation and softwood grafting of wood apple (Feronia limonia L.) genotypes, M.Sc. (Hort.) Thesis, Univ. Agril. Sci., Dharwad (India).

Yadav, V., Singh, A. K., Appa Rao, V. V., Singh, S. and Saroj, P. L., 2018, Wood apple variability-an underutilized dry land fruit from Gujarat, India. Int. J. Curr. Microbiol Appl. Sci.,7(6): 548555.

\section{How to cite this article:}

Sridhar, M. Y., Mr. K. H. Nataraja, Dr. Nagesh Naik, Dr. D. Satish, A. Dileepkumar, Masuthi and Smt. Manjula Karadiguddi 2019. Identification of Elite Woodapple Genotypes for Physical Characters in Selected Districts of Karnataka. Int.J.Curr.Microbiol.App.Sci. 8(09): 1999-2004. doi: https://doi.org/10.20546/ijcmas.2019.809.231 